\title{
Development of Science Learning Device Oriented Guided Inquiry with Virtual Laboratory to Train Science Process Skills of Junior High School Students in Kendari
}

\author{
I Gede Purwana Edi Saputra ${ }^{1, a)}$, Harnipa ${ }^{2, b)}$, Mariani Akhfar ${ }^{2, c)}$ \\ ${ }^{1}$ Department of Physic Education, Universitas Sembilanbelas November Kolaka \\ Jalan Pemuda No.339,Kolaka 93517 Indonesia \\ ${ }^{2}$ Department of Physic Education, Universitas Pancasakti, Makassar, Indonesia
}

$\bowtie:{ }^{a)}$ purwana_physic@usn.ac.id, $\left.{ }^{b}\right)$ Harnipa@unpacti.ac.id, c)mariani.akhfar@unpacti.ac.id

\begin{abstract}
This research was based on the mismatch between the expectation of learning and the study result of IPA on Junior High School. That is why it needs efforts to improve the quality of the teaching and learning process by developing the learning instruments, which are eligible with the mean of IPA and the Graduation Competency Standard on Junior High School. The research purposed to describe the eligibility and effectiveness of the learning instrument of IPA on Junior High School, which is developed in the oriented inquiry by the virtual laboratory to practice the student's science process skills. The research is the development research that adapts the Kemp model. The development of learning instruments such as lesson plans, student worksheets, and assessment sheets. The research subject is the students of class 7 and 8, IX grade on Junior High School 5 Kendari. The implementation planning in-class uses one group pretest and post-test design and data analyzed descriptively. The research results are the learning instruments are eligible to be used, suitable student worksheets, and the student's handbook shows that the content and appearance are interesting. The lesson plan did well, and most students' activity is how to solve a problem. The completeness of the results of the study are well done. Character attitude and social interactive are good. Students' response fir the learning is positive. The summarize of IPA, which is developed, effectively practicing the science process skills for Junior High School students.
\end{abstract}

Keywords: inquiry, virtual laboratory, science process skills

\section{INTRODUCTION}

Alberta Education (2004) explained that the science process skills are the skills students learn when they make a scientific inquiry. The skills of the process are observation, classification, inferencing, forecasting, communicating, measuring, using numbers, interpreting data, conducting experiments, controlling variables, formulating hypotheses, defining operationally, and formulating models (Alonso and Finn 1979). Thus these skills need to be trained in students in science learning (Nikmah and Ellianawati 2019). The skills are included in the cognitive, affective, and psychomotor aspects related to the use of individual intelligence or effectiveness or scientific work or learning outcome that enables success in the learning process with the various way in the school's method or model application (Amaluddin et al. 2019; Harianto et al. 2019; Nursalam et al. 2020; Sejati et al. 2016a, 2016b, 2020).

The science subjects of the technology group aim to have the following abilities: (1) Establish a positive attitude towards science by realizing the order and beauty of nature and glorifying the greatness 
of God Almighty; (2) Fostering a scientific attitude that is honest, objective, open, resilient, critical and can cooperate with others; (3) Develop experience to be able to formulate problems, submit and test hypotheses through experiments, design and assemble experimental instruments, collect, process, and interpret data, and communicate the results of the experiments verbally and in writing; (4) Develop reasoning skills in thinking inductive and deductive analysis using the concepts and principles of science to explain various natural events and solve problems both qualitatively and quantitatively; (5) Mastering the concepts and principles of Natural Science (IPA) and having the skills to develop knowledge, skills and attitudes of confidence as provisions for continuing education at a higher level and developing science and technology; (6) Mastering the basic concepts of science that directly support the achievement of competency program expertise; (7) Applying the basic concept of science to support the application of expertise program competencies in daily life; (8) Applying the basic concept of science to develop the ability of the expertise program at a higher level (MGMP Fisika Surabaya 2013).

Based on the description of the objectives of the science subjects above, it is increasingly evident that science as part of science is a collection of scientific products and consists of processes and attitudes. Thus in learning, science should be oriented to an approach that gives more opportunities for students to develop their ideas by providing a problem that must be found a solution.

For the last few years, the Government of Indonesia has and continues to try to finance educational development programs. One program to develop modern teaching methods in primary and secondary schools over the past few years has emphasized the involvement of students in active learning through inquiry-oriented activities (Aktamis 2008). In line with this, stated in the background of content standards, the standard of competence and essential competencies of SMP for science subjects relates to how to find out about natural phenomena systematically, so that science is not only mastery of a collection of knowledge in the form of facts, concepts, or principles but also a process of discovery. "Inquiry-based teaching is another model of instruction that has been developed to teach students how to think" (Arends 2012). According to (Hidayati 2015; Hidayatiet al. 2017; Sukariasih et al. 2019) guided inquiry emphasizes students finding their knowledge. According to (Nasruddin et al. 2020), guided inquiry makes students more active in the learning process (Ropii, Hardyanto, and Ellianawati 2019).

According to the quotation above, inquiry-based teaching is one of the learning models developed to teach students how students think (using their mental processes). Inquiry processes can occur if learning mainly uses experimental methods (Pyatt and Sims 2012). But in reality, this method is not easy to implement. The experimental approach also has drawbacks that make it difficult for most teachers to implement it. Regarding the lack of experimental methods, namely: requiring a laboratory with adequate equipment and materials, students often have to play in their experimental groups if they are not properly monitored and require relatively longer study times, including time to prepare tools and materials (Kurniawan dan Endah 2010). One solution to overcome this weakness is to use virtual laboratories for the process of experimentation (Efstathiou et al. 2018), such as Physics Education Technology $(\mathrm{PhET})$ simulation media. PhET is a solution that is responsive to the development of learning technology (Finkelstein, Perkins, Adams, Kohl and Podolefsky 2004). The University of Colorado developed phET at American Boulder (the University of Colorado at Boulder) to provide a virtual laboratory simulation of MIPA teaching and learning that facilitates teacher's and student's learning (Keller, Finkelstein, Perkins and Pollock 2005).

Based on the explanation above, it can be understood the nature of science and how science learning should be done. However, what happened in the field was still far from what was supposed to be done, especially in the State Middle Schools in Kendari City, where there were several problems: (1) Science Teachers still often use traditional (informative) methods, where science teaching is emphasized memorizing formulas, concepts, or certain types of issues so that students' involvement in using their mental processes in learning is lacking, (2) Practical activities are very rarely done. This is due to the minimal practicum tools/ materials and the unavailability of science laboratories, (3) The average grade of the IPA semester exam of class IX students is still below the determined Minimum Completeness Criteria (KKM) value. According to (Sejati et al. 2019; Sejati et al. 2020), the students' characteristics in conventional learning are the students' position as a learning object, recipients of information or 
matters, and passive without feedback. According to (Sejati et al. 2017), conventional methods are lectures, discussion, questions, and answers.

Based on the findings above, the researcher proposed an idea to solve the problem by orienting science/ science learning to inquiry. Inquiry activities make students more involved in their mental processes in learning and trained to carry out science process skills. In connection with the science/ science laboratory's unavailability, the researchers proposed using a virtual laboratory using PhET interactive simulation media. The use of PhET interactive simulation media is also following the student majors chosen as research objects, namely the Information and Communication Technology (ICT) department, to easily do it (McKagan, Perkins, Dubson, Malley, Reid, LeMaster and Wieman 2008).

To facilitate learning as proposed above, researchers see the need to develop the learning tools needed. The development of this learning device is also deemed necessary because as far as the researcher's knowledge has not been done, the development of inquiry learning tools has not been done with PhET media to practice the science process skills of junior high school students. The inquiry approach/model is still rarely applied by science/ science teachers because of compiling learning tools that illustrate learning steps with inquiry approaches/models.

\section{METHODS}

This research is research and development (R\&D), which is adapt to the ADDIE model. In the preexperimental treatment phase, it will be tested in 3 (three) groups of class categories (high, medium, and low) based on the average value of the National Final Exam or Ujian Akhir Nasional (UAN) IPA from the population in the last two years. The procedure for developing research includes developing learning devices and the implementation or experimental stages in the classroom. According to (HL et al. 2020), in the research and development, the development result must be implemented or tested in the subject of research, in the case of education topic are students.

Stage of Development of Learning Devices. At this stage, the development of inquiry-based learning tools is carried out using the K13 curriculum: Syllabus, Learning Implementation Plan or Rencana Pelaksanaan Pembelajaran (RPP), Student Activity Sheet or Lembar Kerja Siswa (LKS), and LKS keys, indicators, and rubrics of science process skills to be observed. Before the learning device test, device validation was carried out by a team of experts, teachers, and students. Stage of Implementation in the Class

- . Stage of Try-Out, at this stage teachers, conduct reel teaching in their respective schools, and the observers are teachers of other lesson study participants based on agreed-upon schedule sharing, accompanied by core teachers and researchers. The focus of observation is students' science process skills during learning. The trial results are reflected and corrected, and the experimental learning tool, then validated by the Expert Team.

- . Stage of Implementation (Experiment) at this stage of the study, the teachers at the school designated as the research location were used as model teachers, while the observers were the core teachers and other selected lesson study teachers.

This development research was carried out at state junior high schools in Kendari City, Southeast Sulawesi. The population of this study was all-state junior high school students in Kendari City. The study sample used a purposive random sampling technique.

Data obtained using descriptive analysis. According to (Sejati et al. 2020a, 2020b) the purposive sampling is a process that puts the sample on purpose. According to (Damhuri et al. 2018; Kasnar et al. 2020; Prasetyo et al. 2020; Sejati et al. 2019), the descriptive data analysis technique was popular and sharp to describe the qualitative or quantitative research data with various equipped like percentage, detail survey, or research back analysis in parameter. To determine the validity of the media developed, the Cochran Q-Test was used. In this method, respondents are given closed questions, namely questions whose answer choices consist of yes and no. The calculated $Q$ value is determined through the Cochran Q-Test (Hoaglin, DC 2016). 


\section{RESULTS AND DISCUSSION}

Devices developed, reviewed and assessed, or validated by experts and practitioners competent in their fields are implemented in trials with 13 indicators assessment. The analysis of the media validation instrument was carried out by asking respondents to try to operate the PeTH software and then record their responses through the validation instrument regarding the media, which included the responsibilities of the media. The show aspect is the design and use of use, the use of attractive media, refers to the effectiveness of the media, interactive, image presentation and animation. This lever instrument supervised by four respondents who were competent in terms of media and virtual laboratories. The results of the Q Cochran test for media lever instruments can be seen in the following analysis.

\begin{tabular}{|c|c|c|c|c|c|c|c|c|c|c|c|c|c|c|}
\hline & \multicolumn{14}{|c|}{ item } \\
\hline $\mathrm{n}$ & 1 & 2 & 3 & 4 & 5 & 6 & 7 & 8 & 9 & 10 & 11 & 12 & 13 & $\mathbf{R i}$ \\
\hline 1 & 1 & 1 & 1 & 1 & 1 & 1 & 1 & 1 & 1 & 1 & 1 & 1 & 1 & 13 \\
\hline 2 & 1 & 1 & 1 & 1 & 1 & 1 & 0 & 1 & 1 & 1 & 1 & 1 & 1 & 12 \\
\hline 3 & 1 & 1 & 1 & 1 & 1 & 1 & 1 & 1 & 1 & 1 & 1 & 1 & 1 & 13 \\
\hline 4 & 1 & 1 & 1 & 1 & 1 & 1 & 1 & 1 & 1 & 1 & 0 & 1 & 0 & 11 \\
\hline $\mathrm{Ci}$ & 4 & 4 & 4 & 4 & 4 & 4 & 3 & 4 & 4 & 4 & 3 & 4 & 3 & \\
\hline $\mathrm{Ci}^{2}$ & 16 & 16 & 16 & 16 & 16 & 16 & 9 & 16 & 16 & 16 & 9 & 16 & 9 & \\
\hline $\mathrm{P}(\%)$ & 100 & 100 & 100 & 100 & 100 & 100 & 75 & 100 & 100 & 100 & 75 & 100 & 75 & \\
\hline Kriteria & B & B & B & B & B & B & $\mathrm{CB}$ & $B$ & B & B & CB & B & $\mathrm{CB}$ & \\
\hline
\end{tabular}

\begin{tabular}{|c|c|c|c|c|c|c|c|c|c|c|c|}
\hline k & $\sum \mathrm{n}$ & $k-1$ & $\Sigma \mathrm{Ci}$ & $(\Sigma \mathrm{Ci})^{2}$ & $\Sigma \mathrm{Ci}^{2}$ & $\mathrm{Ri}^{2}$ & $\sum \mathrm{Ri}$ & $\Sigma \mathrm{Ri}^{2}$ & Q & rerata P (\%) & Keterangan \\
\hline 13 & 4 & 12 & 49 & 2401 & 187 & 169 & 49 & 603 & 10.58824 & 94.23 & Baik \\
\hline 13 & 4 & & & & & 144 & & & & & \\
\hline 13 & 4 & & & & & 169 & & & & & \\
\hline 13 & 4 & & & & & 121 & & & & & \\
\hline
\end{tabular}

FIGURE 1. Analysis of the Cochran Q -Test of media validation

The learning tool was tested on 30 students of Class VII, VIII, and IX of Junior High School 5 Kendari. In summary, the implementation of the Learning Implementation Plan during the trial can be seen in FIGURE 1 below, and the picture sample of the developing product can be seen in FIGURE 2 below.

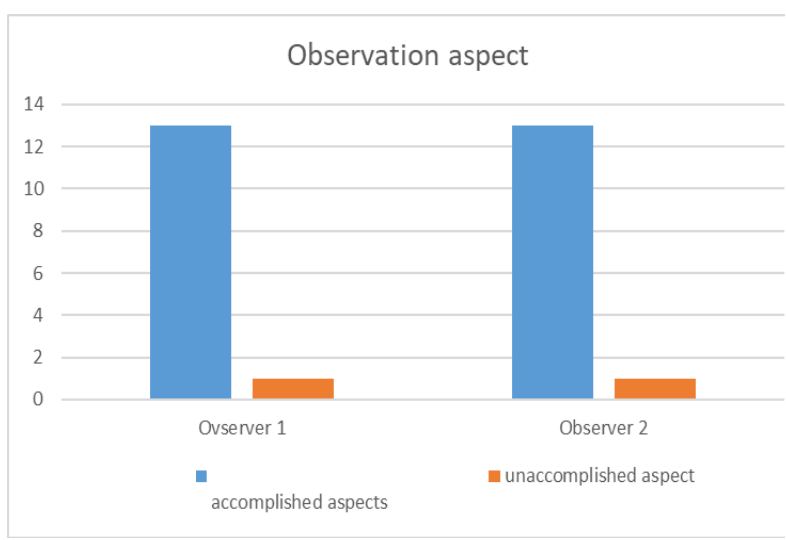

(a)

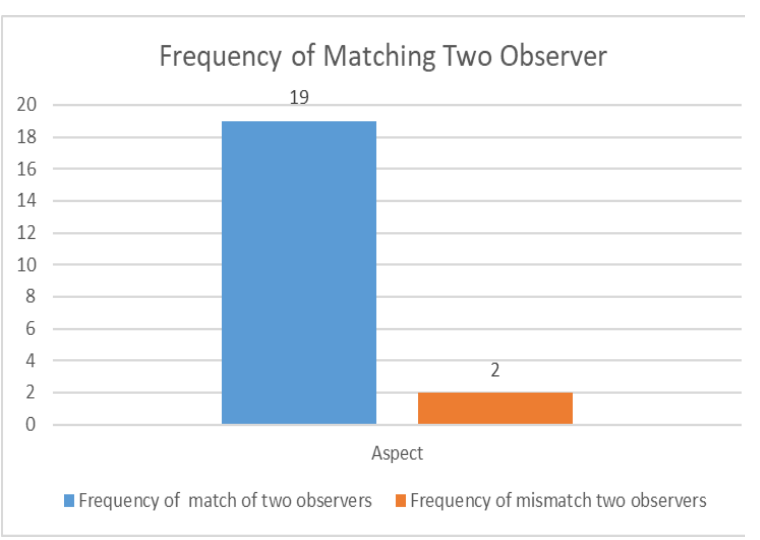

(b)

FIGURE 2. (a) Diagram of observation aspect, (b) Diagram of frequency of matching aspect 


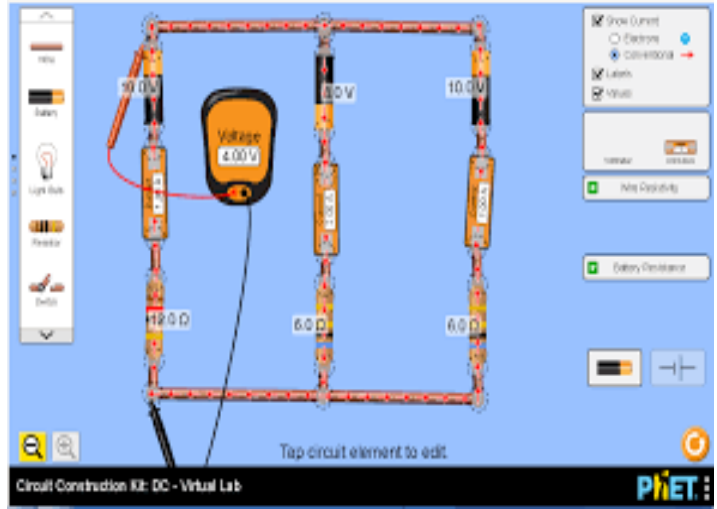

(a)

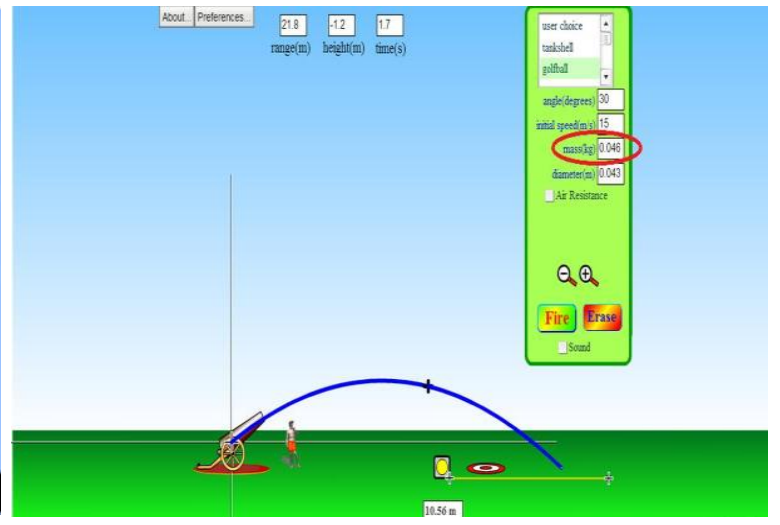

(b)

FIGURE 3. (a) Electrical experiment using PhET simulation, (b) Parabolic motion using PhET simulation

From the diagram analysis in FIGURE 1 (a), it can be seen that Observer 1 and Observer 2 have the same completeness criteria of Learning Implementation Plan in all aspects of 13 indicators of accomplished and each observer evaluates 1 item of unaccomplished elements carried out. FIGURE 1 (b) shows the frequency of matching between the two observers, which is 19 item matching frequencies. This development media trial was conducted on 30 students. The student learning outcomes can be seen in the following TABLE 1.

TABLE 1. Results of Students Individual and Classical Completeness Analysis of Science Process Skills during Trials

\begin{tabular}{lll}
\hline Grade & Frequency & Classical Completeness \\
\hline Complete & 28 & $93.33 \%$ \\
Uncomplete & 2 & $6.67 \%$ \\
\hline
\end{tabular}

The minimum score of standard criteria of completeness is 75 . The results showed that classical completeness was $93.33 \%$, meaning that two students were still incomplete from 30 students. Two students are still having difficulty managing variable controls, carrying out experiments, and making graphics. So the solutions of both students are that these two students need additional special treatment such as improvement or enrichment to guide to complete graduation standards. According to (Sejati et al. 2019), the treatments in guiding people can increase their participation. The analysis of student responses to Student Books and Student Worksheets, learning processes, and process skills can be briefly seen in TABLE 2 below.

TABLE 2. Results of Analysis of Student Response during Trials.

\begin{tabular}{|c|c|c|c|c|c|}
\hline \multirow{2}{*}{$\frac{\text { NO }}{1}$} & \multirow{3}{*}{$\begin{array}{l}\text { DESCRIPTION OF THE QUESTION } \\
\text { Interest in Components: } \\
\text { Subject Matter }\end{array}$} & \multicolumn{4}{|c|}{ ASSESSMENT } \\
\hline & & $\begin{array}{l}\text { Very } \\
\text { interested }\end{array}$ & Interested & $\begin{array}{l}\text { Less } \\
\text { Interested }\end{array}$ & $\begin{array}{l}\text { Not } \\
\text { interested }\end{array}$ \\
\hline & & 50 & 50 & 0 & 0 \\
\hline & Student Worksheet (LKS) & 25 & 50 & 25 & 0 \\
\hline & Exercise with simple KIT & 100 & 0 & 0 & 0 \\
\hline & Learning atmosphere & 50 & 50 & 0 & 0 \\
\hline & Teacher's teaching style & 62.5 & 37.5 & 0 & 0 \\
\hline & Average & 48 & 44 & 8 & 0 \\
\hline & Percentage $(\%)$ & 92 & & 8 & \\
\hline \multirow[t]{8}{*}{2} & Updates for Components: & Very & Update & Less & Not Update \\
\hline & & Update & & Update & \\
\hline & Student Worksheet (LKS) & 25 & 37.5 & 25 & 12.5 \\
\hline & Process skills training & 100 & 0 & 0 & 0 \\
\hline & Learning atmosphere & 100 & 0 & 0 & 0 \\
\hline & Teacher's teaching style & 25 & 75 & 0 & 0 \\
\hline & Average & 60 & 30.0 & 7,5 & 2.5 \\
\hline & Percentage $(\%)$ & 90 & & 10 & \\
\hline
\end{tabular}




\begin{tabular}{|c|c|c|c|c|c|}
\hline NO & DESCRIPTION OF THE QUESTION & & ASS & SSMENT & \\
\hline 3 & Ease of Understanding Components: & Very Easy & Easy & Less Easy & Not Easy \\
\hline & Student Worksheet (LKS) & 0 & 62.5 & 37.5 & 0 \\
\hline & Teacher's teaching style & 12.5 & 87.5 & 0 & 0 \\
\hline & Average & 12.5 & 72.5 & 15.0 & 0 \\
\hline & Percentage $(\%)$ & 85 & & 15 & \\
\hline 4 & Updates in the process skills component & $\begin{array}{l}\text { Very } \\
\text { Update }\end{array}$ & Update & $\begin{array}{l}\text { Less } \\
\text { Update }\end{array}$ & Not Update \\
\hline & Using Tools & 100 & 0 & 0 & 0 \\
\hline & Experiment & 87.5 & 0 & 0 & 12.5 \\
\hline & Formulating problem & 0 & 87.5 & 0 & 12.5 \\
\hline & Formulating hypotesis & 0 & 87.5 & 0 & 12.5 \\
\hline & Determine of manipulation variables & 0 & 87.5 & 0 & 12.5 \\
\hline & Determine of response variables & 0 & 87.5 & 0 & 12.5 \\
\hline & Determine of control variables & 0 & 87.5 & 0 & 12.5 \\
\hline & Determine the operational definition of the variable & 0 & 87.5 & 0 & 12.5 \\
\hline & Planning an experiment & 25 & 75 & 0 & 0 \\
\hline & Do an experiment & 25 & 75 & 0 & 0 \\
\hline & Arrange the data & 75 & 25 & 0 & 0 \\
\hline & Interpreting the data & 75 & 25 & 0 & 0 \\
\hline & Conclude the result of an experiment & 75 & 25 & 0 & 0 \\
\hline & Average & 35.6 & 57.7 & 0,0 & 6.7 \\
\hline & Percentage $(\%)$ & 93 & & 7 & \\
\hline 5 & Ease of following the process & Very Easy & Easy & Less Easy & Not Easy \\
\hline & Using Tools & 12.5 & 87.5 & 0 & 0 \\
\hline & Observation & 0 & 100 & 0 & 0 \\
\hline & Communicating results & 0 & 75 & 25 & 0 \\
\hline & Formulating problem & 0 & 87.5 & 12.5 & 0 \\
\hline & Formulating hypotesis & 12.5 & 87.5 & 0 & 0 \\
\hline & Determine of manipulation variables & 12.5 & 50 & 37.5 & 0 \\
\hline & Determine of response variables & 0 & 62.5 & 37.5 & 0 \\
\hline & Determine of control variables & 0 & 25 & 50 & 25 \\
\hline & Determine the operational definition of the variable & 12.5 & 87.5 & 0 & 0 \\
\hline & Planning an experiment & 0 & 50 & 50 & 0 \\
\hline & Do an experiment & 0 & 62.5 & 25 & 12.5 \\
\hline & Arrange the data & 0 & 75 & 25 & 0 \\
\hline & Interpreting the data & 0 & 75 & 12.5 & 12.5 \\
\hline & Conclude the result of an experiment & 0 & 75 & 25 & 0 \\
\hline & Average & 4.464 & 70.536 & 21.429 & 3.571 \\
\hline & Percentage $(\%)$ & 75 & & 25 & \\
\hline 6 & Interest in using Innovative Learning & $\begin{array}{l}\text { Very } \\
\text { interested }\end{array}$ & Interested & $\begin{array}{l}\text { Less } \\
\text { Interested }\end{array}$ & Not interested \\
\hline & Applied to the next subject & 100 & 0 & 0 & 0 \\
\hline & Applied to other subjects & 100 & 0 & 0 & 0 \\
\hline & Average & 100 & 0 & 0 & 0 \\
\hline & Percentage $(\%)$ & 100 & & 0 & \\
\hline 7 & Clarity in Activities & Very Clear & Clear & Less Clear & Not Clear \\
\hline & $\begin{array}{l}\text { Teacher's explanation during the Teaching And } \\
\text { Learning Process }(\mathrm{Kbm})\end{array}$ & 25 & 75 & 0 & 0 \\
\hline & Teacher guidance when working on worksheets & 37.5 & 62.5 & 0 & 0 \\
\hline & Average & 31.25 & 68.75 & 0 & 0 \\
\hline & Percentage $(\%)$ & 100 & & 0 & \\
\hline
\end{tabular}


TABLE 2 shows that $92 \%$ of students felt interested in the component (teaching material, worksheet, learning atmosphere, and the way the teacher taught), while $8 \%$ of students expressed a lack of interest. Students' responses to the component's renewal indicate that $90 \%$ of students declare new. While $10 \%$ of students stated that they were not new

Students' response to the renewal of the process skills component shows that $93 \%$ of students state new things. While $7 \%$ of students stated, it was not unique. Thus, almost all students say that the process skills component is unknown. Some $85 \%$ of students respond that the component skills process is easy to follow as long as learning activities occur, while $15 \%$ of students state that the skills component of the process is challenging. According to (Nasruddin et al. 2020), the strengths of guided inquiry are that students are more active in the learning process that affects their learning outcome.

Students' response to interest in using the inquiry model with PhET media if applied to the next subject and applied to other lessons is $100 \%$. The student's response to the teacher's explanation when the teaching and learning took place and the teacher's guidance while working on the student worksheets stated that $100 \%$ was clear. The problems faced by researchers during the learning process in small group trials and alternative solutions can be seen in TABLE 3 below. One of the problems is some students get bored. This result is different from Reeves and Crippen (2021) positive outcomes of Vlabs is to improved student motivation.

TABLE 3. Problems of Try-Out

\begin{tabular}{|c|c|c|}
\hline Meeting & \begin{tabular}{|c|} 
Type of Obstacle \\
\end{tabular} & Alternative Solution \\
\hline 1 & $\begin{array}{l}\text { - Students are not accustomed to conducting } \\
\text { the stages of inquiry, so there are some } \\
\text { students who still have difficulties during } \\
\text { learning and need more time to explain it. } \\
\text { - Some students still have difficulty } \\
\text { working with PhET media. } \\
\text { During learning the teacher tends to give a } \\
\text { lot of explanation, so students tend to be } \\
\text { passive. } \\
\text { There are some students who have not } \\
\text { been able to use actual measuring devices. }\end{array}$ & 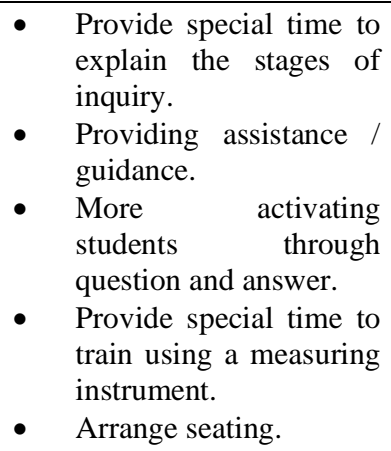 \\
\hline 2 & $\begin{array}{l}\text { - There is one group whose tools are not } \\
\text { functioning, so learning is somewhat } \\
\text { disrupted. }\end{array}$ & - Immediately repaired \\
\hline 3 & $\begin{array}{l}\text { - Some students get bored. } \\
\text { - Students tend to be busy when doing } \\
\text { practice questions }\end{array}$ & $\begin{array}{l}\text { - } \quad \text { Giving motivation. } \\
\text { Remind students not to } \\
\text { be too crowded. }\end{array}$ \\
\hline
\end{tabular}

\section{CONCLUSION}

The conclusions from the research where the development of the tool used in this study obtained criteria valid, effective, and efficient by showing the value of science process skills and the excellent response of students.

\section{ACKNOWLEDGMENT}

This research is internal research of the Sembilanbelas November Kolaka University through the Research Institute and Education Quality Assurance of USN Kolaka collaborated with the Pancasakti University of Makassar. Each author provides ideas in data collection and analysis so that a valid conclusion can be drawn. Thank you as much as possible the researcher said to the leadership of USN Kolaka in providing support and freedom to conduct this research. 


\section{REFERENCES}

Aktamis, H, \& Ergin, O 2008, 'The Effect of Scientific Process Skills Educations on Students Scientific Creativity, Science Attitudes and Academic Achievements', Asia-Pacific Forum on Science Learning and Teaching.

Alberta Education 2004, 'Focus on Inquairy: A Theacher's Guide to Implementing Inquairy-Based Learning', Edmonton, Alberta Education.

Alonso, M \& Finn, EJ 1979, 'Fundamental University Physics', 2nd ed. New York, Addison-Wesley.

Amaluddin, LO, Rahmat, R, Surdin, S, Ramadhan, MI, Hidayat, DN, Sejati, AE, Purwana, IGPE \& Fayanto, S 2019, 'The effectiveness of outdoor learning in improving spatial intelligence', Journal for the Education of Gifted Young Scientists, vol. 7, no. 3, pp. 667-680.

Arends, RI 2012, 'Learning to Teach, Ninth Edition', New York, McGraw Hill Company.

Damhuri, D, Sejati, AE \& Hidayati, DN 2018, 'Adaptation of farmers in rice cultivation at dry season in gunungsari village (Bojonegoro-East Java) for learning source', Proceedings of the UR International Conference on Educational Sciences, pp. 93-9.

Efstathiou, C, Hovardas, T, Xenofontos, NA, et al. 2018 'Providing guidance in virtual lab experimentation: the case of an experiment design tool' Education Tech Research Dev vol. 66, pp. $767-791$.

Finkelstein, ND, Perkins, KK, Adams, WP, Kohl, \& Podolefsky, N 2004, 'Can Computer Simulations Replace Real Equipment in Undergraduate Laboratories?', Boulder, Department of Physics University of Colorado.

Harianto, E, Nursalam, LO, Ikhsan, FA, Zakaria, Z, Damhuri, D, \& Sejati, AE 2019, 'The compatibility of outdoor study application of environmental subject using psychological theories of intelligence and meaningful learning in senior high school', Geosfera Indonesia, vol. 4, no. 2, pp. 201-16.

Hidayati, DN 2015, 'Pengaruh model pembelajaran inkuiri terbimbing (guided inquiry) terhadap kemampuan berpikir kritis siswa SMA pada mata pelajaran geografi [Universitas Negeri Malang]', http://mulok.library.um.ac.id/index3.php/70305.html

Hidayati, DN, Amaluddin, LO, \& Surdin, S 2017, 'The Effect Guided Inquiry to Critical Thinking Ability to Build Student Character in Geography Subject', 1st International Conference on Geography and Education (ICGE 2016), pp. 367-71.

HL, NI, Saputra, IGPE, \& Sejati, AE 2020, 'Developing Teaching Material Bajo's Local Wisdom Sea Preservation Thomson-Brooks/Cole Model', JPI, vol. 9, no. 3, pp. 355-67.

Hoaglin, DC 2016, 'Misunderstandings about Q and 'Cochran's Q test'in meta-analysi', Statistics in medicine, vol. 35, no. 4, pp. 485-95.

Kasnar, S, Hasan, M, Arfin, L, \& Sejati, AE 2020, 'Kesesuaian pemetaan daerah potensi rawan banjir metode overlay dengan kondisi sebenarnya di kota Kendari', Tunas Geografi, vol. 8, no. 2, pp. 8592.

Keller, CJ, Finkelstein, ND, Perkins, KK, \& Pollock, SJ 2005, 'Assessing the effectiveness of a computer simulation in conjunction with Tutorials in Introductory Physics in undergraduate physics recitations', Boulder, Department of Physics University of Colorado.

Kurniawan, W, \& Endah, D 2010, 'Pembelajaran Fisika dengan Metode Inkuiri untuk Mengembangkan Keterampilan Proses Sains', Jurnal Penelitian Pembelajaran Fisika, vol. 1, no. 2, pp. 149-58.

McKagan, SB, Perkins, KK, Dubson, M, Malley, C, Reid, S, LeMaster, R, \& Wieman, CE 2008, 'Developing and Researching PhET Simulations for Teaching Quantum Mechanics', American Journal of Physics, pp. 376-406. 
MGMP Fisika SMP Kota Surabaya 2010, 'Lab Virtual dengan Simulasi Asyik dari Phet', (www.mgmpfis-sma-sby.ucoz.net. 12 Februari 2013).

Nasruddin, N, Mashuri, S, \& Nafiah, U 2020, 'Peningkatan Hasil Belajar Matematika pada Materi Segitiga Melalui Pendekatan Penemuan Terbimbing Siswa SMP', Jurnal Penelitian Dan Pengkajian Ilmu Pendidikan: E-Saintika, vol. 4, no. 2, p. 80.

Nikmah, F \& Ellianawati, E 2019 'Integration of Peer Instruction in the Guided Inquiry Learning Model: Practicing Science Literacy through Scratch', Jurnal Penelitian \& Pengembangan Pendidikan Fisika, vol. 5, no. 2, pp. 177 - 182.

Nursalam, LO, Harianto, E, Hasan, M \& Sejati, AE 2020, 'Nilai-nilai dalam aktualisasi peningkatan karakter kepedulian lingkungan mahasiswa', Tunas Geografi, vol. 8, no. 2, pp. 151-60.

Prasetyo, BE, Mansyur, M, Ikhsan, FA \& Sejati, AE 2020, 'Analisis kelongsoran pengembangan ruas jalan bujangga pinggiran sungai segah Kota Tanjung Redep Kabupaten Berau', Tunas Geografi, vol. 9, no. 1, pp. 33-42.

Pyatt, K \& Sims, R 2012 'Virtual and Physical Experimentation in Inquiry-Based Science Labs: Attitudes, Performance and Access' J Sci Educ Technol vol. 21, pp. 133-147.

Reeves, SM \& Crippen, KJ 2021 'Virtual Laboratories in Undergraduate Science and Engineering Courses: a Systematic Review, 2009-2019’ J Sci Educ Technol vol. 30, pp. 16-30.

Ropii, N, Hardyanto, W \& Ellianawati, E 2019 'Guided Inquiry Scratch Increase Students' Critical Thinking Skills on the Linear Motion Concept: Can it be?', Jurnal Penelitian \& Pengembangan Pendidikan Fisika, vol. 5, no. 1, pp. 63 - 68.

Sejati, AE, Amaluddin, LO, Hidayati, DN, Kasmiati, S, Sumarmi, S, \& Ruja, IN 2017, 'The effect of outdoor study on the geography scientific paper writing ability to construct student character in senior high school', Proceedings of the 5th SEA-DR (South East Asia Development Research) International Conference 2017 (SEADRIC 2017), pp. 104-08.

Sejati, AE, Hasan, M, \& Hidayati, DN 2019, 'The level participation in efforts mount Kelud eruption disaster mitigation in East Java', Harmoni Sosial, Jurnal Pendidikan IPS, vol. 6, no. 1, pp. 100-06.

Sejati, AE, Hasan, M, Nursalam, LO, Harianto, E, \& Deris, D 2020, 'Kesesuaian pemetaan penggunaan lahan pemukiman dengan kondisi sebenarnya di Kecamatan Katobu dan Kecamatan Duruka Kabupaten Muna', Tunas Geografi, vol. 9, no. 1, pp. 55-68.

Sejati, AE, Karim, ATA, \& Tanjung, A 2020, 'The compatibility of a gis map of landslide-prone areas in Kendari City Southeast Sulawesi with actual site conditions', Forum Geografi, vol. 34, no. 1.

Sejati, AE, Kasmiati, S, \& Ikhsan, FA 2019, 'The relationship between learning process interactions and student's learning outcomes in environmental sustainability matter geography-social science education subject', IOP Conference Series, Earth and Environmental Science, vol. 282, p. 012026.

Sejati, AE, Nasarudin, N, \& Ikhsan, FA 2020, 'The effect outdoor study to the students activeness in senior high school', Geographica, vol. 1, no. 1, pp. 7-12.

Sejati, AE, Sumarmi, S, \& Ruja, IN 2016, 'Pengaruh metode pembelajaran outdoor study terhadap kemampuan menulis karya ilmiah geografi untuk meningkatkan karakter cinta lingkungan', Prosiding Nasional Fakultas Ilmu Sosial, Universitas Negeri Malang.

Sejati, AE, Sumarmi, S, \& Ruja, IN 2016, 'Pengaruh metode pembelajaran outdoor study terhadap kemampuan menulis karya ilmiah geografi SMA', Jurnal Pendidikan: Teori, Penelitian, Dan Pengembangan, vol. 1, no. 2, pp. 80-6.

Sukariasih, L, Saputra, IGPE, Ikhsan, FA, Sejati, AE, \& Nisa, K 2019, 'Improving the learning outcomes of knowledge and inquiry skill domain on third grade students of smp negeri 14 Kendari through the guided inquiry learning model assisted by science kit', Geosfera Indonesia, vol. 4, no. 2, pp. 175-87. 
